\title{
SYNTHESIS OF THE AUTOMATIC CONTROL SYSTEM OF THE AUTONOMOUS UNDERWATER VEHICLE AS THE “AGENT" OF THE GROUP
}

\section{СИНТЕЗ СИСТЕМИ АВТОМАТИЧНОГО КЕРУВАННЯ ВЕДЕНИМ АВТОНОМНИМ НЕНАСЕЛЕНИМ ПІДВОДНИМ АПАРАТОМ ЯК «АГЕНТОМ» ГРУПИ}

\author{
Volodymyr S. Blintsov \\ volodymyr.blintsov@nuos.edu.ua \\ ORCID: 0000-0002-3912-2174 \\ Leo T. Aloba \\ aloba.leo.tosin@nuos.edu.ua \\ ORCID: 0000-0002-0509-8129
}

\author{
В. С. Блінцов, \\ д-р техн. наук, професор \\ Л. Т. Алоба, \\ викладач
}

\author{
Admiral Makarov National University of Shipbuilding, Mykolaiv \\ Національний університет кораблебудування імені адмірала Макарова, м. Миколаїв
}

\begin{abstract}
Growing demands on the performance of underwater exploration work stimulate the simultaneous use of a group of autonomous unmanned vehicle. The organization of such underwater missions requires the creation of highly efficient systems of automatic control of each individual autonomous unmanned vehicle as an "agent" of a group of vehicles moving at the same depth at the same course and speed. This mode is called "alignment". At the same time, it is necessary to automatically ensure the maximum distance between the autonomous unmanned vehicle, sufficient to maintain a reliable sonar connection between them, i.e. the "cohesion" mode, and to exclude the emergency convergence of neighboring submarines, i.e. the "adhesion" mode.

The aim of the work is to develop a generalized algorithm. structures of the system of automatic control of the conducted autonomous unmanned vehicle as "agent" of group of submarines which carry out the joint underwater mission.

To achieve this goal, the methods of automatic control theory for the synthesis of the control system, fuzzy logic methods for the synthesis of the laws of control of the underwater vehicle, the mathematical apparatus of matrix theory for modeling the processes of individual units of the synthesized control system.

The result is a generalized process of functioning of the automatic control system of the autonomous unmanned vehicle as an "agent" of the group, which implements the modes of alignment, adhesion and cohesion as the main modes of group movement. This uses information from its own navigation sensors and additional sensors of the navigation environment, modeling of the navigation environment around it and identification of navigation threats.

The scientific novelty is the development of the structure of the automatic control system of the autonomous unmanned vehicle as an "agent" of the group, which includes the block "Navigation environment sensors", block "Navigation situation model", block "Navigation threat identifier" and block "On-board control computer" and also in development of matrix information models of functioning of the specified.

The practical significance of the research lies in the creation of a theoretical basis for further applied developments of autonomous unmanned vehicle control systems, which will increase the productivity of group underwater search missions. Key words: autonomous unmanned vehicle; group application; automatic control system; alignment; adhesion; cohesion.
\end{abstract}

Анотація. Щораз більші вимоги до продуктивності виконання підводних пошукових робіт стимулюють одночасне застосування групи автономних ненаселених підводних апаратів. Організація таких підводних місій вимагає створення високоефективних систем автоматичного керування кожним окремим підводним апаратом як «агентом» групи апаратів, які рухаються на однаковій глибині одним курсом і швидкістю. Такий режим іменується «вирівнюванням». Одночасно необхідно автоматично забезпечити максимальну дистанцію між підводними апаратами, достатню для утримання надійного гідроакустичного зв'язку між ними, тобто режим «когезії», та усунути аварійне зближення сусідніх підводних апаратів, тобто режим «адгезії».

Метою роботи є розроблення узагальненого алгоритму, структури системи автоматичного керування веденим автономним ненаселеним підводним апаратом як «агентом» групи підводних апаратів, які виконують спільну підводну місію. 
Для досягнення поставленої мети використано методи теорії автоматичного керування для синтезу системи керування, методи нечіткої логіки для синтезу законів керування рухом підводного апарата, математичний апарат теорії матриць для моделювання процесів функціонування окремих блоків синтезованої системи керування таким апаратом.

Результатом роботи є розроблений узагальнений процес функціонування системи автоматичного керування веденим автономним ненаселеним підводним апаратом як «агентом» групи, який реалізує режими вирівнювання, адгезії та когезії як основні режими групового руху. Для цього використовується інформація від його власних навігаційних сенсорів і додаткових сенсорів навігаційної обстановки, моделювання навігаційної обстановки навколо нього та ідентифікації навігаційних загроз.

Наукова новизна полягає у розробленні структури системи автоматичного керування веденим автономним ненаселеним підводним апаратом як «агентом» групи, яка містить блок «Сенсори навігаційної обстановки», блок «Модель навігаційної обстановки», блок «Ідентифікатор навігаційних загроз» і блок «Бортовий керуючий контролер», а також у розробленні матричних інформаційних моделей функціонування вказаних.

Практична значимість дослідження полягає у створенні теоретичного підгрунтя для подальших прикладних розроблень систем керування веденим підводним апаратом, що дасть змогу підвищити продуктивність групових підводних пошукових місій.

Ключові слова: автономний ненаселений підводний апарат; групове застосування; система автоматичного керування; вирівнювання; адгезія; когезія.

\section{ПОСТАНОВКА ЗАДАЧІ}

Збільшення обсягів підводних робіт і постійне вдосконалювання технічних характеристик АНПА стимулюють новий напрямок їхньог застосування - одночасне групове використання на великих акваторіях (в англомовній літературі - multi-agent systems, MAS). Це забезпечує найбільшу ефективність підводних робіт - максимальну продуктивність пошукових операцій i максимальну вірогідність одержуваних даних про підводне середовище через паралельні у часі виміри його параметрів [1;2]. Для таких робіт сьогодні створюються спеціальні види АНПА, які призначені для проведення пошукових, науково-дослідних і інших підводних робіт у рамках реалізації групових технологій, коли збір даних про морське середовище або підводний пошук виконуються одночасно декількома АНПА за спільною програмою [3-6].

Отже, нині актуальним прикладним науковим завданням автоматизації керування окремим АНПА групи є синтез систем автоматичного керування (САК) його рухом в умовах групового переходу. Така система повинна виключати зіткнення або надмірне збільшення відстані між сусідніми АНПА, що може викликати, відповідно, аварійну ситуацію або розпад групи і зрив підводної місії.

\section{АНАЛІЗ ОСТАННІХ ДОСЛІДЖЕНЬ І ПУБЛІКАЦЙ}

Розроблення методів автономної роботизиваної навігації є одним з основних напрямів підводної робототехніки [7].

Постійний прогрес у технології підводних апаратів і акустичного зв'язку зробив реальним скоординоване керування групою АНПА, яка може складатися з функціонально різних апаратів (різнорідних), які можуть розрізнятися по крейсерській швидкості й діапазонам каналів гідроакустичного зв'язку. Наприклад, ц [8; 9] описано систему програмного забезпечення САК для роботизиваних платформ (MOOS (Mission Oriented Operating Suite), яка грунтується на архітектурі «публікації-підписки» [10]. Така САК була застосована для координації керування групою АНПА для рішення пошукових операцій. У вказаній роботі застосовано методологію «Iv Helm» (інтервальне програмування) для формулювання й розв'язку багатоцільових завдань оптимізації. Ця методологія є основним компонентом для формування модулів MOOS-I, які забезпечують автономність на роботизованих гетерогенних платформах [11].

У [12] також запропоновано модель на основі множинного сенсорного керування для запобігання зіткнень і відстеження заданої траєкторії руху мобільного робота. Ці методи скорочують час і споживання енергії.

Низку наукових робіт присвячено аналізу підходів до побудови САК на базі нечіткої логіки, оскільки цей метод забезпечує високий ступінь стійкості керування й стійкість роботи в умовах перешкод. Зокрема, у [13; 14] було запропоновано моделювання нечітких контролерів 3 ковзним режимом для АНПА без використання системної моделі й представлені результати експерименту АНПА, використовуючи нечіткий закон керування з ковзним режимом. У [15] автори використовують нечітку логіку й візуальні датчики для уникнення перешкод для колісного робота. Одна $з$ переваг цього методу - високий ступінь стабільності й імунітету від зовнішніх збурень. У порівнянні з іншими методами керування нечіткий регулятор має найвищий ступінь свободи в установленні параметрів і має просте математичне забезпечення [16]. 


\section{ВІДОКРЕМЛЕННЯ НЕ ВИРІШЕНИХ РАНІШЕ ЧАСТИН ЗАГАЛЬНОЇ ПРОБЛЕМИ}

Крім переваг вказаних вище підходів до побудови систем керування та використаних моделей руху АНПА, вони мають низку огріхів.

Зокрема, під час виконання місій не розглядаються питання безаварійного руху окремого АНПА під час групової місії команди АНПА. Під час виконання місії АНПА можуть бути занадто близько один від одного, що може викликати проблеми для групи АНПА.

Крім того, існує ймовірність того, що окремі АНПА будуть переміщатися занадто далеко від заданих робочих зон групи АНПА й тим самим втратять зв'язок один $з$ одним, що несприятливо вплине на продуктивність їхньої підводної місії чи навіть зробить неможливим її виконання.

Тому нині актуальним є завдання синтезу ефективної САК АНПА для узгодженого руху апаратів у груповому переході.

\section{МЕТА ДОСЛІДЖЕННЯ}

Метою дослідження є розроблення узагальненого алгоритму та структури системи автоматичного керування веденим автономним ненаселеним підводним апаратом як «агентом» групи підводних апаратів, що виконують спільну підводну місію.

\section{МЕТОДИ, ОБ'СКТ ТА ПРЕДМЕТ ДОСЛІДЖЕННЯ}

Об'єктом дослідження є керований автоматично рух групи АНПА в режимах групового переходу та групового виконання спільної підводної пошукової мiciï.

Предметом дослідження є автоматичне керування безаварійним рухом одиночного $i$-го веденого АНПА як «агента» групи в умовах навігаційної близькості інших підводних апаратів.

Дослідження проводяться методами класичної теорії автоматичного керування (для синтезу системи автоматичного керування), методами нечіткої логіки (для синтезу законів керування рухом веденого АНПА як «агента» групи) та теорії матриць (для математичного моделювання процесів функціонування окремих блоків синтезованої системи керування АНПА).

\section{ОСНОВНИЙ МАТЕРІАЛ}

1. Розроблення узагальненого процесу функціонування САК $\boldsymbol{i}$-м веденим АНПА як «агентом» групи підводних апаратів

Розглядаємо плоский рух $i$-го веденого АНПА як «агента» групи під час виконання етапів розгортання АНПА в групу та іiї групового переходу до робочої зони акваторіях як типових етапів для організації групового руху [17].

Функціонування САК $i$-м веденим АНПА як «агентом» групи підводних апаратів, що виконує під- готовчі операції та, власне, груповий перехід, опишемо у вигляді алгоритму, поданому на рис. 1.

Дамо опис його роботи в порядку нумерації блоків алгоритму.

Б1 - опитування ведучого АНПА-1 відносно поточного етапу базової роботизованої технології автоматичного виконання пошукових підводних місій; тут також вводяться завдання на груповий перехід та задані з базового рівня керування В:

- значення параметрів руху $M_{3}=\left\{v_{3}, \varphi_{3}, h_{3}\right\}$, де $v_{3}, \varphi_{3}, h_{3}$ - відповідно, задані швидкість лінійного руху, курс і глибина занурення АНПА при їх груповому русі;

- значення стартових географічних координат веденого АНПА $\left\{\Phi_{3} ; \Lambda_{3}\right\}$.

Б2 - умовний перехід $X_{1}$, який містить підготовчі операції САК веденим АНПА як «агентом» групи підводних апаратів:

$x_{11}-$ перехід до блоку Б3 завантаження до пам'яті бортового керуючого контролера веденого АНПА програми виконання поточної пошукової місії; для цього використовується канал морського радіозв'язку та радіогідроакустичні буї [18];

$x_{12}$ - перехід до блоку Б4 виконання етапу самоорганізації випущених АНПА (автоматичного формування групи) для подальшого колективного переходу до робочої зони, де буде виконуватись пошукова підводна місія; виконання цього етапу передбачає встановлення гідроакустичного зв'язку з сусідніми АНПА, занурення за задану глибину $h_{3}$ та розворот веденого апарата на заданий курс $\varphi_{3}$;

$x_{13}-$ перехід до блоку Б5 ініціалізації виконання поточного етапу пошукової місії, де за допомогою бортового керуючого контролера веденого АНПА виконуються підготовчі операції для забезпечення його безаварійного групового руху - перевірка працездатності навігаційних сенсорів АНПА та сенсорів навігаційної обстановки навколо нього.

Б6 - блок опитування сенсорів навігаційної системи (СНС) $i$-го веденого АНПА, які дають інформацію $I_{C H C i}$ про фактичні значення його лінійної $v_{i}$ та кутової $\omega_{i}$ швидкостей АНПА, курсу $\varphi$ та глибина занурення $h_{i}$.

Б7 - блок опитування сенсорів навігаційної обстановки (CHO) навколо $i$-го веденого АНПА; тут отримується інформація $D_{3 C}$ про АНПА-сусідів по групі, які рухаються паралельними курсами і можуть створювати навігаційні перешкоди руху для $i$-го веденого АНПА; зазвичай, це дистанція $d_{i j}$ до $j$-го АНПА-сусіда та пеленг $\alpha_{i j}$ або курсовий кут $K K_{i j}$ на цей апарат.

Б8 - блок аналізу та моделювання навігаційної обстановки (МНО) навколо $i$-го веденого АНПА; тут на основі інформації від Б7 виділяються дистанції та пеленги (курсові кути) до найбільш небезпечних (найближчих) АНПА-сусідів, які створюють навігаційні загрози для $i$-го веденого АНПА; інформація 


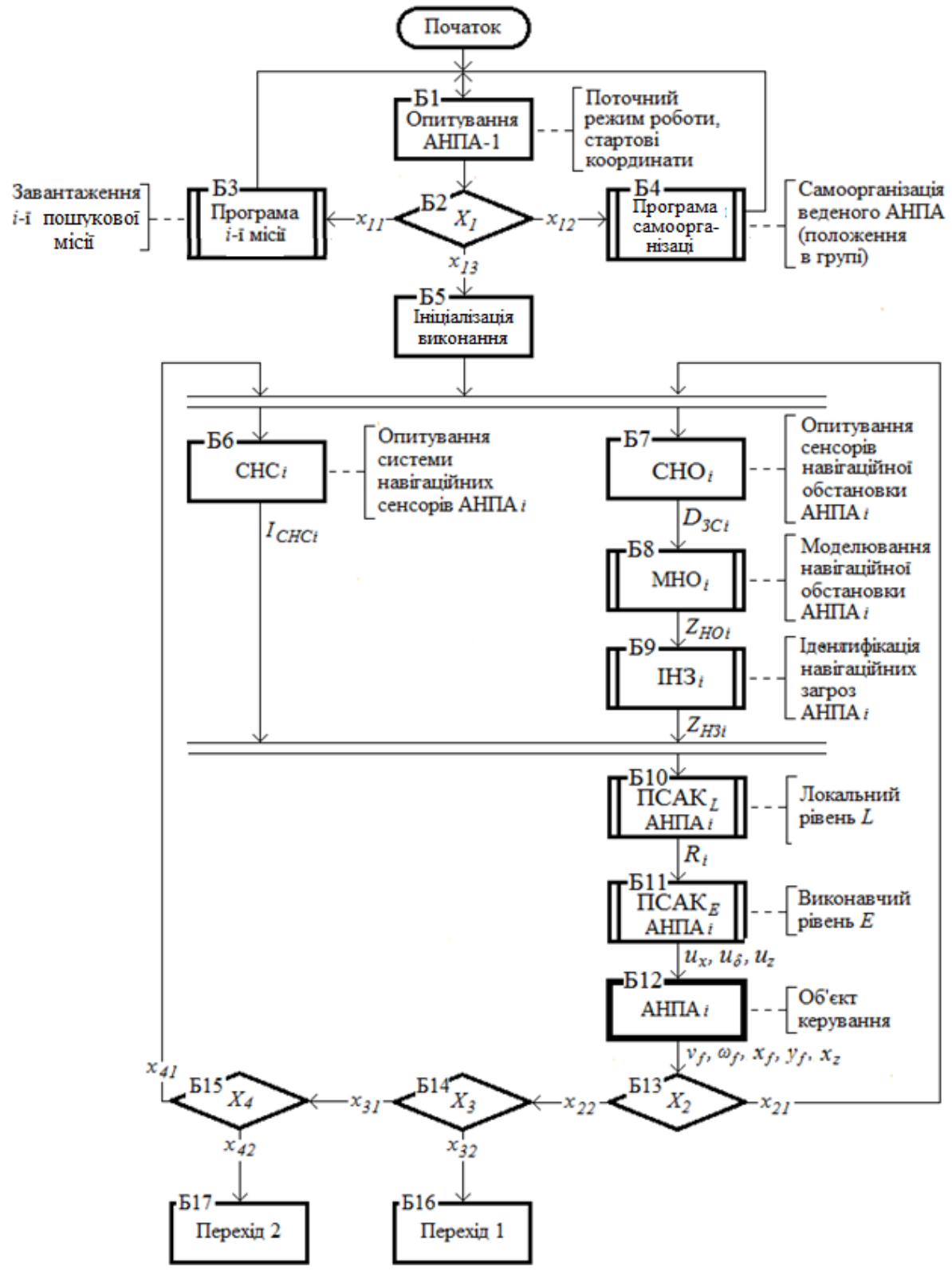

Рис. 1. Узагальнений алгоритм функціонування системи автоматичного керування $i$-м веденим АНПА в режимі групового переходу

$Z_{H O}$ про виділених АНПА-сусідів використовується для подальшої оцінки ступеню навігаційної небезпеки для $i$-го веденого АНПА.

Б9 - блок аналізу та ідентифікації навігаційних загроз (ІНЗ) для $i$-го веденого АНПА; тут визначаються статичні й динамічні характеристики руху АНПАсусідів, на основі чого кількісно оцінюються можливі ризики зіткнень або втрати зв' язку з ними в результаті неприпустимого збільшення дистанції; тут також за результатами отриманих оцінок можливих загроз від АНПА-сусідів формуються рекомендації щодо нейтралізації кожної виявленої загрози шляхом маневрування $i$-го веденого АНПА; зазначена інформація $Z_{H 3}$ слугує основою для обчислення керуючого впливу на $i$-й ведений АНПА з урахуванням групових загроз, які діють одночасно.

Б10 - блок має забезпечити локальний рівень $L$ автоматичного керування рухом $i$-го веденого АНПА в умовах навігаційних загроз двох типів - навігаційної близькості сусідніх підводних апаратів групи та можливої втрати гідроакустичного зв'язку з сусідніми АНПА з-за неприпустимо великої дистанції до них (більшої, ніж радіус дії бортових систем зв'язку апаратів); цей рівень забезпечується підсистемою ПСАК ${ }_{L}$ (множина рекомендацій $R_{i}$ щодо безпечного руху $i$-го веденого АНПА). 


\section{АВТОМАТИЗАЦІЯ ТА КОМП'ЮТЕРНО-ІНТЕГРОВАНІ ТЕХНОЛОГІЇ № 4〜 2020}

Б11 - блок має реалізувати виконавчий рівень $E$ автоматичного керування рухом $i$-го веденого АНПА шляхом підтримання заданих значень курсу і швидкості лінійного руху (підсистема ПСАК ${ }_{E}$ ); вихідними сигналами блоку Б11 $є$ сигнали керування частотою обертання гребного електродвигуна (ГЕД) $u_{x}$ (керування швидкістю $v_{x i}$ ), приводом стерна рушійно-стернового комплексу (РСК) $i$-го веденого АНПА $u_{\delta i}$, який змінює кут перекладки стерна $\delta_{R i}$, а також сигнал $u_{z i}$ керування кутом перекладки стерна вертикального руху АНПА при аварійній зміні глибини занурення.

Б12 - об'єкт керування ( $i$-й ведений АНПА), основними виходами якого $є$ фактичні значення лінійної $v_{f}$ і кутової $\omega_{f}$ швидкостей АНПА та поточні координати його плоского руху $\left(x_{f}, y_{f}\right)$.

Б13 - умовний перехід $X_{2}$, який контролює продовження (умова $x_{21}$ ) чи завершення (умова $x_{22}$ ) завершення маневру безпечного розходження 3 АНПАсусідом.

Б14 - умовний перехід $X_{3}$, який контролює завершення етапу групового переходу за ознакою розрахункової тривалості місії і забезпечує продовження етапу (умова $x_{31}$ ) або перехід до блоку Б16 (умова $x_{32}$ ) для виконання наступного етапу місії.

Б15 - умовний перехід $X_{4}$, який контролює показники енергетичного забезпечення етапів (умови $x_{41}$ та $x_{42}$ ); у разі зниження енергетичних показників джерела енергії $i$-го веденого АНПА (умова $x_{42}$ ) виконується перехід до блоку Б17 (умова $x_{42}$ ) для дострокового завершення місії цим підводним апаратом.

Запропонований узагальнений алгоритм функціонування САК $i$-м веденим АНПА в режимі групового переходу відтворює основні завдання для системи автоматичного керування групою АНПА і, таким чином, утворює методологічну основу для розробки окремих найбільш складних складових такої САК.

2. Розроблення структури системи автоматичного керування веденим АНПА як «агентом» групи

Аналіз завдань групового керування АНПА у зазначених етапах виконання морської місії свідчить, що одним із ключових є завдання забезпечення безпечного (безаварійного) руху окремого веденого АНПА у групі на заданій глибині $h_{3}=h_{M A S}$ заданим курсом $\varphi_{3}$ та $з$ заданою швидкістю $v_{3}$.

Теоретичною основою автоматизації такого руху $\epsilon$ поняття вирівнювання $A_{\mathrm{GU}}$, адгезії $A_{\mathrm{GA}}$ та когезії $A_{\mathrm{GC}}$ [19]. Розглянемо їх детальніше.

Поняття вирівнювання передбачає утримання стабільними трьох вище зазначених параметрів автоматичного руху групи АНПА:

$$
A_{\mathrm{GU}}=\left\{\varphi_{3} ; v_{3} ; h_{3}\right\},
$$

що вимагає руху групи АНПА у заданому напрямі чи по заданій просторовій траєкторії та автоматичне керування рухом окремого АНПА як агента групи у заданому напрямку із рекомендованою заданою швидкістю та на заданій глибині, однаковій для всіх АНПА групи.

Поняття адгезії передбачає завдання кожному АНПА як агенту групи рухатись 3 урахуванням $A_{\mathrm{GU}}$ та одночасним контролем мінімально можливої дистанції між окремим агентом та його сусідами, безпечної з позицій зіткнення:

$$
A_{\mathrm{GA}}=\left.\left\{x_{i} \geq x_{\min }\right\}\right|_{i=1 \ldots W},
$$

де $x_{i}$-дистанція від $i$-го веденого АНПА до сусіднього АНПА за курсовим кутом $K K_{i}$;

$x_{\text {min }}$ - мінімально можлива безпечна дистанція до сусіднього АНПА;

$W$ - кількість напрямків (курсових кутів), контрольованих відповідними навігаційними далекомірами $i$-го веденого АНПА.

Поняття когезії передбачає завдання кожному агенту групи рухатись 3 урахуванням $A_{\mathrm{GU}}$ та одночасним контролем максимально можливої дистанції між $i$-м веденим АНПА та його сусідами, безпечної 3 позицій втрати сенсорного контакту (наприклад, гідроакустичного зв'язку) i, як наслідок, втрати групи АНПА у результаті їі «розпорошення»:

$$
A_{\mathrm{GC}}=\left.\left\{x_{i} \leq x_{\max }\right\}\right|_{i=1 \ldots .},
$$

де $x_{\max }$ - максимально припустима дистанція між $i$-м веденим АНПА та сусіднім АНПА, при якій зберігається надійний сенсорний контакт між ними.

У ролі далекомірів АНПА можуть бути використані підводні гідроакустичні, лазерні чи електричні сенсори, що мають забезпечувати системі автоматичного керування підводного апарата чутливість до сусідніх АНПА, які рухаються у складі групи [20;21].

Кількість сенсорів та їхні діаграми направленості залежать від низки вимог до групового руху АНПА та від особливостей виконання пошукової підводної місії. Зазвичай кількість сенсорів варіюється у межах від 4 до 12 і забезпечує вимірювання дистанцій між АНПА за відповідними курсовими кутами у межах від 0,1 м до 20 м, що дає можливість будувати ефективні системи керування груповим рухом засобів підводної робототехніки.

Очевидно, що під час виконання загальної вимоги (1) для уникнення зіткнень 3 сусідніми АНПА $i$-й ведений підводний апарат має два основні види маневру - маневр курсом і маневр швидкістю руху.

Маневр по глибині будемо вважати аварійним, а його застосування - граничним заходом збереження веденого АНПА в групі.

Для оцінки ступеня загрози зіткнень між агентами групи АНПА пропонується до складу САК $i$-го веденого АНПА ввести спеціальні блоки:

блок «Модель навігаційної обстановки» (МНО) навколо відповідного АНПА;

блок «Ідентифікатор навігаційних загроз» (IH3) для цього $i$-го АНПА. 
Будувати вказані блоки доцільно із залученням теорії нечіткої логіки [22]. Це пов'язано з властивостями $i$-го веденого АНПА як об'єкту керування, для якого характерним $\epsilon$ недостатність та невизначеність інформації, що ускладнює застосування класичних аналітичних методів синтезу регуляторів.

Розгляньмо призначення цих блоків більш детально.

Головне завдання функціонування МНО для $i$-го веденого АНПА полягає у формуванні для нього поточної підводної навігаційної обстановки - виявлення $K$ найближчих АНПА-сусідів, які утворюють загрозу зіткнення та $M$ найвіддаленіших АНПА-сусідів, які утворюють загрозу втрати контакту з контрольованих далекомірами $W$ напрямків, а також визначення дистанцій до них.

Призначенням блоку IHЗ $є$ визначення статичних і динамічних параметрів руху кожного з виявлених АНПА-сусідів за $W$ напрямками, кількісне обчислення рівня загрози зіткнення чи втрати контакту з ним (характеристик адгезії та когезії свого АНПА по відношенню до найближчих АНПА-сусідів) та, одночасно, формування рекомендацій щодо нейтралізації виявленої загрози шляхом маневрування курсом, швидкістю та, у разі крайньої необхідності, глибиною занурення.

Узагальнена структура САК одиночним АНПА як агентом групи наведена на рис. 2 (для зручності індекс «і» опущено).

Розгляньмо основні принципи функціонування наведеної САК, беручи до уваги узагальнений алгоритм функціонування САК.

Блок «Сенсори навігаційної обстановки» $i$-го веденого АНПА (блок Б7 на рис. 1) містить набір з $W$ сенсорів групового руху (сенсорів контрольованих напрямків для вимірювання дистанцій до цілей, які виявляються в секторах їх вимірювань).

На виході блоку СНО формуються множини сигналів про дистанції до сусідніх АНПА групи (по наростаючій - від меншого до більшого) $D_{3 C}=\left\{D_{3 C l} ; \ldots\right.$ $\left.D_{3 C w} ; \ldots D_{3 C w}\right\}$ та пеленги $\mathrm{A}_{3 C}$ чи курсові кути $K K_{3 C}$ на них.
Очевидно, що кожний елемент множини сигналів $D_{3 C w}$ може містити декілька дистанцій $d_{w i}$, якщо у секторі вимірювань $w$-го сенсора знаходиться декілька АНПА-сусідів.

Курсові кути $K K_{w}$ (пеленги $\alpha_{w}$ ) на такі АНПА будуть однаковими і визначаються розташуванням відповідного сенсора на корпусі АНПА у зв'язаній системі координат [23].

Тоді множину $D_{3 C}$ можна представити однойменною матрицею $D_{3 с i}$ дистанцій від $i$-го веденого АНПА до сусідніх АНПА, яка має розмі р $[W \times N]$, де $W-$ кількість сенсорів (контрольованих напрямків) навігаційної обстановки $i$-го веденого АНПА; $N$ - кількість АНПА в групі:

$$
D_{3 C i}=\left[\begin{array}{ccccc}
d_{11 i} & \ldots & d_{1 i i} & \ldots & d_{1 N i} \\
\ldots & \ldots & \ldots & \ldots & \ldots \\
d_{w 1 i} & \ldots & d_{w i i} & \ldots & d_{w N i} \\
\ldots & \ldots & \ldots & \ldots & \ldots \\
d_{W 1 i} & \ldots & d_{W i i} & \ldots & d_{W N i}
\end{array}\right] .
$$

Блок «Моделювання навігаційної обстановки» (блок Б8 на рис. 1) на основі сигналів $D_{3 C i}$ формує поточну статичну та динамічну характеристики цілей (АНПА-сусідів) навколо свого АНПА, визначає $K$ найближчих АНПА-сусідів, які утворюють найбільшу загрозу зіткнення для нього та визначає $M$ найвіддаленіших від нього АНПА-сусідів, що утворюють загрозу неприпустимо великої відстані від нього і втрати гідроакустичного зв'язку (відповідно, вихідні змінні $Z_{\mathrm{HO}-\mathrm{Ki}}$ i $Z_{\mathrm{HO}-\mathrm{Mi}}$ ) [24].

У блоці МНО виконуються такі операції:

- визначаються мінімальні $D_{H о-K i}$ та максимальні $D_{H о-м і}$ дистанції до виявлених АНПА-сусідів та визначаються пеленги на них $\left(\mathrm{A}_{H о-к i}, \mathrm{~A}_{H O-м i}\right)$ та/чи курсові кути $\left(K K_{H O-M i}, K K_{H O-M i}\right)$;

- за допомогою обчислювача похідних (ОП) визначаються динамічні характеристики руху виявлених АНПА-сусідів по груповому руху - лінійні швидкості руху $K K_{\text {Hо-кi }}$ з якими вони змінюють дистанцію до $i$-го веденого АНПА та лінійні швидкості руху $K K_{H O-м i}, 3$ якими вони змінюють дистанцію до нього

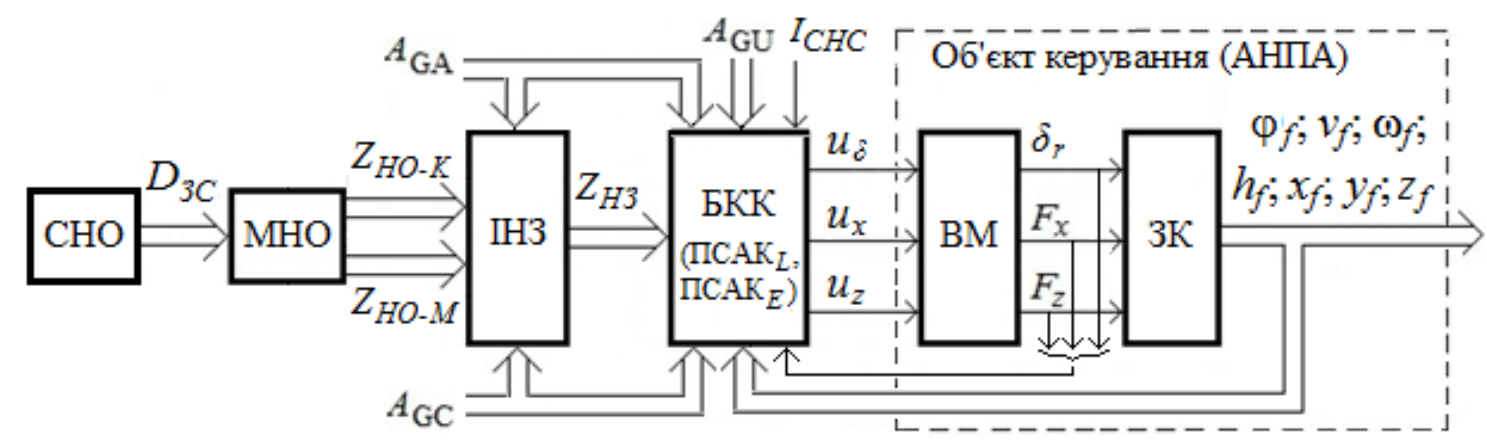

Рис. 2. Структура САК одиночним АНПА як агентом групи 


\section{АВТОМАТИЗАЦІЯ ТА КОМП'ЮТЕРНО-ІНТЕГРОВАНІ ТЕХНОЛОГІЇ № 4 2020}

3 контрольованих напрямків, що визначаються $W$ сенсорами СНО.

У результаті формується дві множини параметрів, які характеризують навігаційну обстановку навколо $i$-го веденого АНПА:

$$
\begin{aligned}
& Z_{H O-K i}=\left\{D_{H O-K i} ; \mathrm{A}_{H O-K i} ; K K_{H O-K i} ; V_{H O-K i}\right\}, \\
& Z_{H O-M i}=\left\{D_{H O-M i} ; \mathrm{A}_{H O-M i} ; K K_{H O-M i} ; V_{H O-M K i}\right\},
\end{aligned}
$$

де $K \leq W$ i $K \leq N$.

Для зручності подальшого використання при синтезі САК $i$-м веденим АНПА отримані множини параметрів доцільно представити двома парами матриць розміром $[W \times K]$ та $[W \times M]$, у яких статичні і динамічні характеристики АНПА-сусідів зв'язані з сенсорами контрольованих напрямків блоку СНО (зазвичай, курсовими кутами, оскільки сенсори $i$-го веденого АНПА закріплені на його ЗК і мають прив'язку до зв'язаної системи координат), а саме:

двома матрицями дистанцій до найближчих АНПА-сусідів $D_{H O-K i}$ та швидкостей їх зближення чи віддалення $V_{\text {HO-Кi }}$ :

$$
\begin{aligned}
D_{H O-K i} & =\left[\begin{array}{ccccc}
d_{11 i} & \ldots & d_{1 k i} & \ldots & d_{1 K i} \\
\ldots & \ldots & \ldots & \ldots & \ldots \\
d_{w 1 i} & \ldots & d_{w k i} & \ldots & d_{w K i} \\
\ldots & \ldots & \ldots & \ldots & \ldots \\
d_{W 1 i} & \ldots & d_{W k i} & \ldots & d_{W K i}
\end{array}\right], \\
V_{H O-K i} & =\left[\begin{array}{ccccc}
v_{11 i} & \ldots & v_{1 k i} & \ldots & v_{1 K i} \\
\ldots & \ldots & \ldots & \ldots & \ldots \\
v_{w 1 i} & \ldots & v_{w k i} & \ldots & v_{w K i} \\
\ldots & \ldots & \ldots & \ldots & \ldots \\
v_{W 1 i} & \ldots & v_{W k i} & \ldots & v_{W K i}
\end{array}\right] .
\end{aligned}
$$

двома матрицями дистанцій до найвіддаленіших АНПА-сусідів $D_{H O-м i}$ та швидкостей зміни дистанцій до них $V_{\text {но-мі }}$ :

$$
\begin{aligned}
D_{H O-M i} & =\left[\begin{array}{ccccc}
d_{11 i} & \ldots & d_{1 m i} & \ldots & d_{1 M i} \\
\ldots & \ldots & \ldots & \ldots & \ldots \\
d_{w 1 i} & \ldots & d_{w m i} & \ldots & d_{w M i} \\
\ldots & \ldots & \ldots & \ldots & \ldots \\
d_{W 1 i} & \ldots & d_{W m i} & \ldots & d_{W M i}
\end{array}\right], \\
V_{H O-M i} & =\left[\begin{array}{ccccc}
v_{11 i} & \ldots & v_{1 m i} & \ldots & v_{1 M i} \\
\ldots & \ldots & \ldots & \ldots & \ldots \\
v_{w 1 i} & \ldots & v_{w m i} & \ldots & v_{w M i} \\
\ldots & \ldots & \ldots & \ldots & \ldots \\
v_{W 1 i} & \ldots & v_{W m i} & \ldots & v_{W M i}
\end{array}\right] .
\end{aligned}
$$

Зазначимо, що інформація $D_{H о-K i}$ та $V_{H о-к i}$ необхідна для реалізації, власне, режимів адгезії і когезiі, а інформація $D_{\text {но-мі }}$ і $V_{H о-м і}$ - для реалізації більш складних алгоритмів групового керування, наприклад, коли $i$-й ведений АНПА бере на себе функції ведучого АНПА групи.
Таким чином, елементи матриць $D_{H O-K i} \subset Z_{H O i}$, $D_{H O-M i} \subset Z_{H O i}, \quad V_{H O-K i} \subset Z_{H O i}$ та $V_{H O-M i} \subset Z_{H O i}$ містять інформацію про дистанції до $K$ та $M$ навігаційно небезпечних сусідніх АНПА та про швидкості ї зміни за $W$ напрямками (у більшості випадків за курсовими кутами $K K_{3 C-K i}$ та $\left.K K_{3 C-M i}\right) i$-го веденого АНПА, які контролюються відповідними його сенсорами $\mathrm{CHO}_{i}$.

Вказані матриці утворюють інформаційне підгрунтя для кількісної оцінки навігаційних загроз навколо $i$-го веденого АНПА.

Блок ідентифікації навігаційних загроз (блок Б9 на рис. 1) оцінює ступінь загрози зіткнення 3 АНПА-сусідами та/чи загрозу втрати гідроакустичного контакту з ними у випадку плоского горизонтального руху згідно залежностей (32) та (3) 3 урахуванням динаміки руху групи $3 k \in K$ виявленими найближчими АНПА-сусідами та $3 m \in M$ виявленими найвіддаленішими АНПА-сусідами за $w \in W$ контрольованими напрямками.

Очевидно, що для організації безпечного руху $i$-го веденого АНПА у складі групи достатнім $\epsilon$ урахування навігаційних загроз лише від одного найближчого і, значить, найбільш небезпечного, АНПА-сусіда 3 кожного контрольованого напрямку $w \in W$. Це пояснюється тим, що за наявності на $w$-му контрольованому напрямку декількох АНПА-сусідів найбільшу загрозу зіткнення (чи втрати контакту з групою) несе саме найближчий АНПА-сусід.

Одночасно гідроакустичний зв'язок 3 ним гарантує $i$-му веденому АНПА зв'язок 3 групою у цілому $\mathrm{i}$, значить, його збереження як «агента» у складі групи. При цьому, якщо найбільш віддалений АНПА-сусід з $M$ виявлених підводних апаратів має тенденцію до збільшення дистанції з $i$-м веденим АНПА з загрозою втрати гідроакустичного зв'язку з ним, це не призведе до «розпорошення» групи, оскільки такий зв'язок будуть підтримувати АНПА, які знаходяться між цими двома апаратами.

Однак, якщо 3 w-го напрямку АНПА-сусідів, що загрожують зіткненням, не виявлено, актуальним є завдання контролю дистанції до найближчого АНПА-сусіда, який віддаляється від $i$-го веденого АНПА. Це пояснюється загрозою втрати $i$-м веденим АНПА зв'язку з групою і, як наслідок, його втратою як «агента» групи.

Тому кожну з множин $Z_{\text {HО-Кi }}$ i $Z_{H O-м і}$ у форматі (5) і (6) необхідно представити двома матрицямистовбцями навігаційних загроз розміром [ $W \times 1]$ кожна, які містять інформацію, відповідно, про дистанції $d_{w i}$ між $i$-м веденим АНПА та виявленим найближчим АНПА-сусідом за кожним $3 w \in W$ контрольованих напрямків, а також про швидкість $v_{w i}$ зміни цих дистанцій до них у процесі руху $i$-го веденого АНПА у складі групи: 


$$
\begin{aligned}
& D_{H 3-K_{1} i}=\left[\begin{array}{c}
d_{1 K_{1} i} \\
\ldots \\
d_{w K_{1} i} \\
\ldots \\
d_{W K_{1} i}
\end{array}\right] ; \quad V_{H 3-M_{1} i}=\left[\begin{array}{c}
v_{1 M_{1} i} \\
\ldots \\
v_{w M_{1} i} \\
\ldots \\
v_{W M_{1} i}
\end{array}\right] . \\
& D_{H 3-M_{1} i}=\left[\begin{array}{c}
d_{1 M_{1} i} \\
\ldots \\
d_{w M_{1} i} \\
\ldots \\
d_{W M_{1} i}
\end{array}\right] ; \quad V_{H 3-M_{1} i}=\left[\begin{array}{c}
v_{1 M_{1} i} \\
\ldots \\
v_{w M_{1} i} \\
\ldots \\
v_{W M_{1} i}
\end{array}\right] \text {. }
\end{aligned}
$$

де $K_{1}, M_{1}$ - індекси, які характеризують віднесення змінних, відповідно, до мінімальних і максимальних дистанцій до АНПА-сусідів.

Одночасно у блоці IНЗ формується множина $P_{H 3 i}$ рекомендацій щодо нейтралізації кожної окремої (одиночно діючої) w-ї виявленої загрози.

Очевидно, що таку нейтралізацію можливо реалізувати шляхом маневрування курсом $\varphi_{i}$, швидкістю $v_{i}$ та, у разі крайньої необхідності, зміною глибини занурення $h_{i} i$-го веденого АНПА.

Множину рекомендацій $P_{\text {ні }}$ доцільно представити однойменною матрицею розміром [ $W \times 3]$, елементи якої містять рекомендовані керуючі реакції $i$-го веденого АНПА на кожну $w$-ту виявлену загрозу за припущення, що вона є єдиною поточною загрозою для $i$-го веденого АНПА у даний момент часу:

$$
P_{H 3 i}=\left[\begin{array}{c}
p_{H 31 i} \\
\ldots \\
p_{H 3 w i} \\
\ldots \\
p_{H 3 W i}
\end{array}\right]=\left[\begin{array}{ccc}
\Delta \varphi_{1 i} & \Delta v_{1 i} & \Delta h_{1 i} \\
\ldots & \ldots & \ldots \\
\Delta \varphi_{w i} & \Delta v_{w i} & \Delta h_{w i} \\
\ldots & \ldots & \ldots \\
\Delta \varphi_{W i} & \Delta v_{W i} & \Delta h_{W i}
\end{array}\right],
$$

де $p_{н з w i}=\left\{\Delta \varphi_{w i}, \Delta v_{w i}, \Delta h_{w i}\right\}-$ відповідно, рекомендовані курс, лінійна швидкість та глибина руху $i$-го веденого АНПА для нейтралізації $w$-ї виявленої загрози.

Отже, інформація про кожну окрему ідентифіковану навігаційну загрозу з $w$-го напрямку $(w \in W)$ для $i$-го веденого АНПА на виході блоку ІНЗ (див. рис. 1) може бути представлена такими матрицями:

$$
Z_{H 3 i}=\left\{D_{H 3-K 1 i} ; V_{H 3-K 1 i} ; P_{H 3 i}\right\} .
$$

Отримані матриці можуть бути використані як базові рішення для організації безпечного руху $i$-го веденого АНПА за умови, коли його СНО виявила лише одного навігаційно небезпечного АНПА-сусіда (матриця $P_{H 3 i}$ ) та для обчислення маневру $i$-го веденого АНПА, коли виявлено навігаційно небезпечні АНПА-сусіди одночасно з декількох напрямків.

Бортовий керуючий контролер (БКК) САК $i$-м веденим АНПА виконує триєдину задачу для локального $L$ та виконавчого $E$ рівнів керування:
- для локального рівня $L$ групового керування підводними апаратами $\left(\right.$ ПСАК $\left.\mathrm{L}_{L i}\right)$ - на основі матриць $Z_{H 3 i}$ $=\left\{D_{H 3-\kappa i} ; V_{H 3-\kappa i} ; P_{H з i}\right\}$, обчислених згідно залежностей (11)-(13), формує керуюче рішення $R_{i}$ для реального маневрування $i$-го веденого АНПА, щоб уникнути ідентифікованих в IHЗ одиночної чи групових загроз $w \in W:$

$$
R_{i}=\left\{\Delta \varphi_{i} ; \Delta v_{i} ; \Delta h_{i}\right\} .
$$

- для виконавчого рівня $E$ групового керування підводними апаратами (ПСАК $\left.{ }_{E i}\right)$ - формує керуючі впливи $\left\{u_{\delta i} ; u_{x i} ; u_{z i}\right\}$ на виконавчі механізми (ВМ) $i$-го веденого АНПА - відповідно, привод стерна РСК (керована величина - кут перекладки стерна $\delta_{r}$ ), маршовий рушійний пристрій (керована величина - кутова частота обертання ГЕД $\omega_{x}$ або упор по поздовжній осі $F_{x}$ ) та, в аварійних випадках, привод горизонтального стерна РСК (керована величина - кут перекладки стерна $\delta_{z}$ ) 3 метою реалізації режимів адгезії $A_{\mathrm{GA}}$ та когезії $A_{\mathrm{GC}}$ згідно (2) і (3);

- для виконавчого рівня $E$ групового керування підводними апаратами $\left(\right.$ ПСАК $\left._{E i}\right)$ - формує керуючі впливи $\left\{u_{\delta i} ; u_{x i} ; u_{z i}\right\}$ на ВМ $i$-го веденого АНПА відповідно, на привод стерна РСК (керована величина - кут перекладки стерна $\delta_{r}$ ), маршовий рушійний пристрій (керована величина - кутова частота обертання ГЕД $\omega_{x}$ або упор по поздовжній осі $F_{x}$ ) та привод горизонтального стерна РСК (керована величина - кут перекладки стерна $\delta_{z}$ ) 3 метою реалізації режиму $A_{\mathrm{GU}}$ «вирівнювання» $i$-го веденого АНПА, тобто утримання заданих йому параметрів руху згідно (1) з використанням інформації $I_{C H C i}$ від блоку Б6 (рис. 1).

Отже, ц блоці БКК САК $i$-м веденим АНПА як «агентом» групи визначаються такі керівні впливи:

- на локальному рівні $L$ групового керування (блок Б10 на рис. 1) формується рекомендація $R_{i \in} L_{A g}$ для його безпечного руху у складі групи;

- на виконавчому рівні обчислюються керуючі впливи $\left\{u_{\delta i} ; u_{x i} ; u_{z i}\right\}$ для виконання умов (1)-(3) керованого руху $i$-го веденого АНПА як «агента» групи дотримання режимів вирівнювання, адгезії та когезії.

Вищезазначені керуючі впливи, прикладені до ЗК АНПА, обумовлюють появу фактичних змінних просторового руху $i$-го веденого АНПА - $\left\{\varphi_{f} ; v_{f} ; \omega_{f} ; h_{f} ; x_{f}\right.$; $\left.y_{f}\right\}$, які у якості сигналів зворотного зв'язку використовуються в БКК його САК.

Принципи синтезу основних блоків такої САК розгляньмо нижче.

3. Розроблення блоку «Ідентифікатор навігаційних загроз»

Вхідними даними для роботи блоку IНЗ є матриці $D_{H O-К i} \subset Z_{H O i}$ та $V_{H O-К i} \subset Z_{\text {HОi }}$ згідно (7) і (9), які містять інформацію про дистанції до $K$ навігаційно небезпечних сусідніх АНПА та про швидкості їх зміни за $W$ напрямками. 


\section{АВТОМАТИЗАЦІЯ ТА КОМП'ЮТЕРНО-ІНТЕГРОВАНІ ТЕХНОЛОГІЇ № 4〜 2020}

Як зазначалось вище, у блоці ІН3 $i$-го веденого АНПА виконуються наступні перетворення навігаційної інформації:

- шляхом аналізу матриці $D_{H о-к i}$ визначається найближчий АНПА-сусід за кожним з $W$ напрямків, який утворює найбільшу загрозу зіткнення з $i$-м веденим АНПА $з$ цього напрямку:

$$
\begin{gathered}
\inf \left\{\left.d_{1 k i}\right|_{k=1, \ldots K}\right\}=d_{1 K i} ; \\
\ldots \\
\inf \left\{\left.d_{w k i}\right|_{k=1, \ldots K}\right\}=d_{w K i} ; \\
\ldots \\
\inf \left\{\left.d_{W k i}\right|_{k=1, \ldots K}\right\}=d_{W K i} .
\end{gathered}
$$

- шляхом аналізу матриці $D_{H о-м і}$ визначається найвіддаленіший АНПА-сусід для $i$-го веденого АНПА, який утворює загрозу неприпустимо великої відстані від нього і пов'язаної з цим загрози втрати гідроакустичного зв'язку між ними:

$$
\begin{gathered}
\sup \left\{\left.d_{1 m i}\right|_{m=1, \ldots M}\right\}=d_{1 M i} ; \\
\ldots \\
\sup \left\{\left.d_{w k i}\right|_{m=1, \ldots M}\right\}=d_{w M i} ; \\
\ldots \\
\sup \left\{\left.d_{W k i}\right|_{m=1, \ldots M}\right\}=d_{W M i} .
\end{gathered}
$$

Для відібраних дистанцій $d_{w K i}$ та $d_{w M i}$ обчислюються перші їх похідні, тобто швидкості зміни дистанцій до них $v_{w K i}$ та $v_{w M i}$.
Отже, за допомогою залежностей (16) і (17) отримуємо пари матриць $D_{H 3-K i}, V_{H 3-K i}$ та $D_{H 3-м i}, V_{H 3-м i}$ згідно (1) i (12).

Загалом, відношення (4)-(17) утворюють матричні інформаційні моделі функціонування вказаних блоків синтезованої системи автоматичного керування веденим АНПА як «агентом» групи.

Розгляньмо тепер особливості обчислення матриці рекомендацій $P_{H з і}$ згідно з (13).

Розглядаємо випадок, коли блок $\mathrm{CHO} i$-го веденого АНПА виявив лише одного навігаційно небезпечного АНПА-сусіда.

Як було зазначено вище, будувати блок IН3 у цілому і обчислення матриці рекомендацій $P_{H 3 i}$, зокрема, доцільно проводити із застосуванням теорії нечіткої логіки [22]. Водночас фазифікація вхідних змінних (11)-(12) для кожної пари $\left\{d_{w K i} ; v_{w K i}\right\}$ та $\left\{d_{w M i} ; v_{w M i}\right\}$ у блоці IHЗ може бути виконана уведенням таких лінгвістичних змінних:

для дистанцій $d_{w K i}$ та $d_{w M i}$ :

$D_{B}-$ дистанція велика (є загроза втрати зв'язку 3 цим АНПА-сусідом);

$D_{C}-$ дистанція середня;

$D_{\text {Onm }}$ - дистанція оптимальна (бажана);

$D_{M}$ - дистанція мала;

$D_{H}$ - дистанція небезпечно мала (є загроза зіткнення $з$ АНПА-сусідом);

для швидкостей $v_{w K i}$ та $v_{w M i}$ :

$V_{3 в}$ - швидкість зближення велика;

$V_{3 C}$ - швидкість зближення середня;

$V_{3 м}$ - швидкість зближення мала;

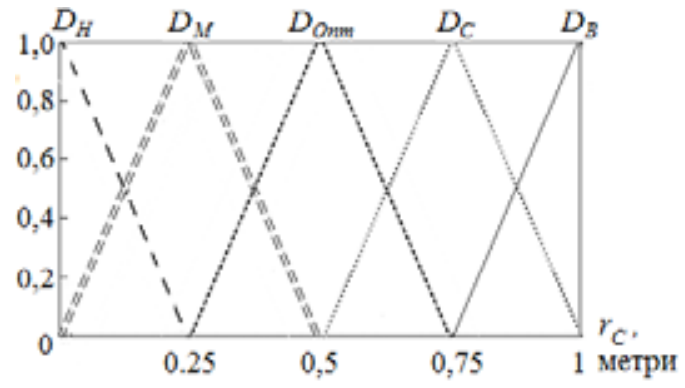

\begin{tabular}{|l|l|l|}
\hline$D_{B}$ & - & Велика \\
\hline$D_{C}$ & $\cdots \cdots$ & Середня \\
\hline$D_{\text {Orм }}$ & $\cdots \cdots \cdots$ & Оптимальна \\
\hline$D_{M}$ & $====$ & Мала \\
\hline$D_{H}$ & $-\cdots$ & Небезпечна \\
\hline
\end{tabular}

a
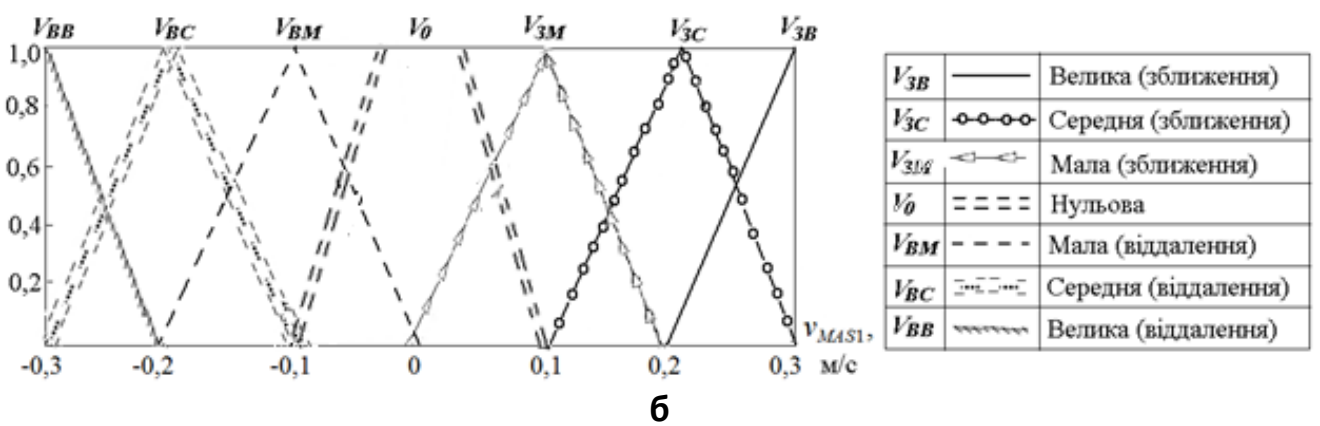

Рис. 3. Функції належності: а - вхідна змінна «дистанція до АНПА-сусіда», метри; б - вхідна змінна «швидкість зближення/віддалення», м/с 
$V_{0}$ - нульова швидкість зближення (бажана);

$V_{B M}$ - швидкість віддалення мала;

$V_{B C}$ - швидкість віддалення середня;

$V_{B B}-$ швидкість віддалення велика.

Функції приналежності дистанцій та швидкостей їх зміни доцільно представити у формі трикутних функцій (trimf), рис. 3, де в ролі максимальної дистанції між $i$-м веденим АНПА та АНПА-сусідом попередньо як чисельний приклад прийнято радіус дії бортової системи зв'язку $r_{C} i$-го веденого АНПА, а в ролі максимальної швидкості зміни дистанції між цими АНПА прийнято третину заданої швидкості групового руху АНПА $v_{3}$.

Представимо кожний елемент матриці рекомендацій $P_{H з ш і}$ базою правил $Б П_{P_{н з}}$, яка містять рекомендовані реакції ВМ $i$-го веденого АНПА на виявлену одиничну загрозу $з$ w-го напрямку. Зазначені правила мають реалізовувати режими адгезії і когезії згідно (2)-(3)

Попередній досвід синтезу баз правил для реакції ВМ $i$-го веденого АНПА на загрози з різних контрольованих напрямків свідчить, що при наявності лише однієї виявленої загрози рекомендовані реакції його ВМ мають однакову логіку роботи i, як наслідок, одна- кову структуру отриманих рекомендацій. Це пов'язано 3 тим, що незалежно від кута пеленгу на загрозу $i$-й ведений АНПА має маневром курсу чи швидкості ухилитись від неї, а при неможливості такого маневру виконати маневр одночасно за курсом і швидкістю або тимчасово змінити глибину занурення.

Завдання синтезу всієї множини таких маневрів належить до проєктних робіт під час інженерного проєктування регуляторів.

Як приклад розгляньмо $i$-й ведений АНПА, який має чотири сенсори навігаційної обстановки $(W=4)$ : один - на носу АНПА, другий - на кормі, третій і четвертий - побортно зліва і справа [25] (див. рис. 4).

Розгляньмо структуру бази правил для випадку, коли сусідній АНПА виявлено правим бортовим сенсором $i$-го веденого АНПА, що контролює загрози по поперечній осі $y$ зв'язаної системи координат АНПА (матриця рекомендацій $P_{H з w i-Y}$, база правил $Б \Pi_{Р_{н з-Ү}}$ ).

Для зручності запису складники кожного елемента $p_{H 3 w i}=\left\{\Delta \varphi_{w i}, \Delta v_{w i}, \Delta h_{w i}\right\}$ матриці $P_{H з w i}$ запишемо у вигляді стовпця (див. табл. 1).

У табл. 1 позначено:

$\Delta \varphi_{\text {wiм(м,c,s) }}$ - рекомендації щодо кута $\delta_{r}$ перекладки стерна РСК $i$-го веденого АНПА для зменшення дис-

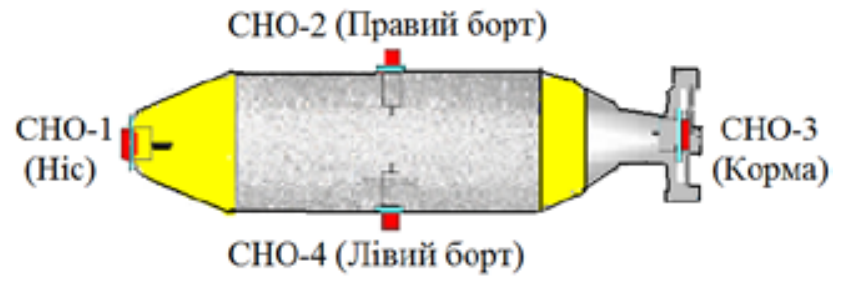

$a$

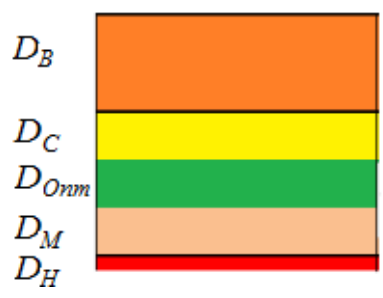

$\sigma$

Рис. 4. Розташування сенсорів навігаційного зв'язку на ЗК і-го веденого АНПА (а) та градація дистанцій до АНПА-сусідів

Таблиця 1

База правил БП ${ }_{P н з-Y}$ блоку IНЗ (правий бортовий сенсор)

\begin{tabular}{|c|c|c|c|c|c|c|c|c|}
\hline & \multicolumn{7}{|c|}{ Швидкість зближення/віддалення $V_{H 3}$} \\
\hline & & $V_{3 B}$ & $V_{3 C}$ & $V_{3 M}$ & $V_{0}$ & $V_{B M}$ & $V_{B C}$ & $V_{B B}$ \\
\hline \multirow{5}{*}{ 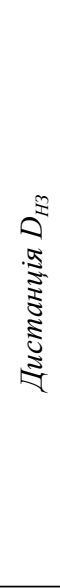 } & $D_{B}$ & $\begin{array}{l}0 \\
0 \\
0\end{array}$ & $\begin{array}{l}0 \\
0 \\
0\end{array}$ & $\begin{array}{l}0 \\
0 \\
0\end{array}$ & $\begin{array}{c}\Delta \varphi_{\text {wiMc }} \\
0 \\
0\end{array}$ & $\begin{array}{c}\Delta \varphi_{w i M c} \\
0 \\
0\end{array}$ & $\begin{array}{c}\Delta \varphi_{\text {wiMe }} \\
0 \\
0\end{array}$ & $\begin{array}{c}\Delta \varphi_{w i M c} \\
0 \\
0\end{array}$ \\
\hline & $D_{C}$ & $\begin{array}{c}\Delta \varphi_{\text {wibc }} \\
0 \\
0 \\
\end{array}$ & $\begin{array}{c}\Delta \varphi_{\text {wibM }} \\
0 \\
0\end{array}$ & $\begin{array}{l}0 \\
0 \\
0\end{array}$ & $\begin{array}{c}\Delta \varphi_{w i M M} \\
0 \\
0\end{array}$ & $\begin{array}{c}\Delta \varphi_{w i M c} \\
0 \\
0\end{array}$ & $\begin{array}{c}\Delta \varphi_{w i M e} \\
0 \\
0 \\
\end{array}$ & $\begin{array}{c}\Delta \varphi_{w i M t} \\
0 \\
0 \\
\end{array}$ \\
\hline & $D_{\text {Onm }}$ & $\begin{array}{c}\Delta \varphi_{\text {wibs }} \\
0 \\
0\end{array}$ & $\begin{array}{c}\Delta \varphi_{\text {wibc }} \\
0 \\
0\end{array}$ & $\begin{array}{c}\Delta \varphi_{\text {wibM }} \\
0 \\
0 \\
\end{array}$ & $\begin{array}{l}0 \\
0 \\
0\end{array}$ & $\begin{array}{c}\Delta \varphi_{w i M u} \\
0 \\
0\end{array}$ & $\begin{array}{c}\Delta \varphi_{w i M c} \\
0 \\
0 \\
\end{array}$ & $\begin{array}{c}\Delta \varphi_{w i M c} \\
0 \\
0 \\
\end{array}$ \\
\hline & $D_{M}$ & $\begin{array}{c}\Delta \varphi_{\text {wibs }} \\
0 \\
0\end{array}$ & $\begin{array}{c}\Delta \varphi_{\text {wibs }} \\
0 \\
0\end{array}$ & $\begin{array}{c}\Delta \varphi_{\text {wibc }} \\
0 \\
0\end{array}$ & $\begin{array}{c}\Delta \varphi_{\text {wibn }} \\
0 \\
0\end{array}$ & $\begin{array}{l}0 \\
0 \\
0\end{array}$ & $\begin{array}{l}0 \\
0 \\
0\end{array}$ & $\begin{array}{l}0 \\
0 \\
0\end{array}$ \\
\hline & $D_{H}$ & $\begin{array}{c}0 \\
0 \\
\Delta h_{w i} \\
\end{array}$ & $\begin{array}{c}0 \\
0 \\
\Delta h_{w i} \\
\end{array}$ & $\begin{array}{c}\Delta \varphi_{w i b b} \\
0 \\
0\end{array}$ & $\begin{array}{c}\Delta \varphi_{w i b c} \\
0 \\
0\end{array}$ & $\begin{array}{c}\Delta \varphi_{\text {wib. }} \\
0 \\
0\end{array}$ & $\begin{array}{l}0 \\
0 \\
0\end{array}$ & $\begin{array}{l}0 \\
0 \\
0\end{array}$ \\
\hline
\end{tabular}




\section{АВТОМАТИЗАЦІЯ ТА КОМП'ЮТЕРНО-ІНТЕГРОВАНІ ТЕХНОЛОГІЇ № 4〜 2020}

танції до виявленої одиничної загрози з $w$-го напрямку (режим когезії); відповідно, $м$ - малий кут перекладки, $c$ - середній кут перекладки, 6 - великий кут перекладки;

$\Delta \varphi_{\text {wib(M,c,s) }}-$ рекомендації щодо кута $\delta_{r}$ перекладки стерна РСК $i$-го веденого АНПА для збільшення дистанції до виявленої одиничної загрози з $w$-го напрямку (режим адгезії); значення індексів аналогічні вище описаним);

$\Delta h_{w i}$ - рекомендація по зміні глибини занурення $i$-го веденого АНПА; тут і далі вважаємо, що такий маневр носить тимчасовий характер і після деякого визначеного часу цей АНПА повертається на задану глибину $h_{3}$ та поновлює аналіз навігаційної обстановки.

Аналогічну форму мають бази правил для маневрування швидкістю $\Delta v_{w i}$ при виявленні одиночної загрози по осі $x$ зв'язаної системи координат. При цьому у табл. 1 замість рекомендації $\Delta \theta_{w i}$ щодо зміни кута перекладки стерна РСК має бути рекомендація $\Delta v_{w i}$ зміни швидкості лінійного руху $i$-го веденого АНПА

Дефазифікацію змінної $\Delta \varphi_{w i}$ (рекомендацій щодо нейтралізації окремої $w$-ї виявленої загрози) запишемо у вигляді функції приналежності $\varphi_{w i}=f\left(\Delta \varphi_{w i}\right)$, представленої на рис. 5.

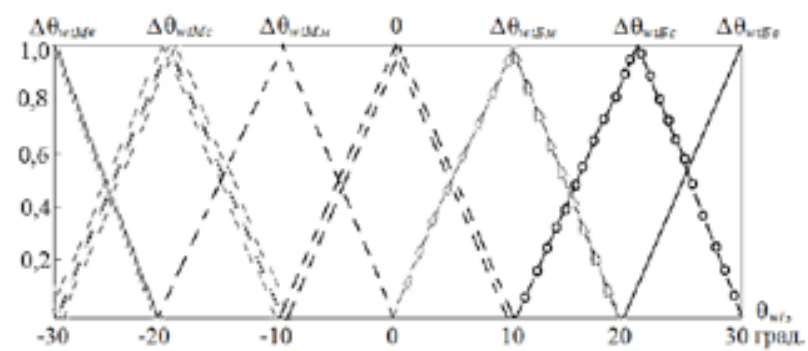

Рис. 5. Функція належності: вихідна змінна - кут перекладки стерна
У результаті на виході блоку ІНЗ одночасно 3 матрицями $D_{H 3-K} ;$ i $V_{H 3-K i}$ формується матриця $P_{H 3 i}$ виду (13), яка містить рекомендації щодо маневрів $i$-го веденого АНПА для ухилення від одиночних навігаційних загроз за $W$ контрольованими напрямками.

Реалізація множини рекомендацій покладена на бортовий керуючий контролер (БКК) САК $i$-м веденим АНПА (рис. 1).

Розроблення блоку «Бортовий керуючий контролер». Указаний блок (позначимо БКК) допомагає розв'язати три основні завдання:

Завдання № 1: формування керуючого рішення $R_{i}$ для реального маневрування $i$-го веденого АНПА 3 метою уникнення зустрічі з одиночною $R_{1}$ чи груповою $R_{W}$ загрозою та, одночасно, з метою зберегти себе у складі групи, не втративши зв'язок з найближчим АНПА-сусідом (локальний рівень $L$ групового керування, підсистема ПСАК $)_{L}$;

Завдання № 2: формування керуючих впливів на ВМ $i$-го веденого АНПА з метою реалізації його безпечного руху у складі групи АНПА з дотриманням вимог режимів адгезії $A_{\mathrm{GA}}$ та когезії $A_{\mathrm{GC}}$ (виконавчий рівень $E$ групового керування, підсистема $\Pi \mathrm{\Pi AK}_{E}$ );

Завдання № 3: формування керуючих впливів на ВМ $i$-го веденого АНПА з метою реалізації режиму $A_{\mathrm{GU}}$ «вирівнювання» $i$-го веденого АНПА, тобто утримання заданих йому параметрів руху як «агента» групи АНПА (виконавчий рівень $E$ групового керування, підсистема ПСАК ${ }_{E}$ ).

Структура блоку БКК, що забезпечує виконання вказаних функцій, наведена на рис. 6. Розгляньмо призначення модулів блоку БКК.

Модуль «Аналіз рівня загроз» (АР3) визначає кількість контрольованих напрямків, за якими одночасно існують навігаційні загрози для $i$-го веденого АНПА від найближчих АНПА-сусідів.

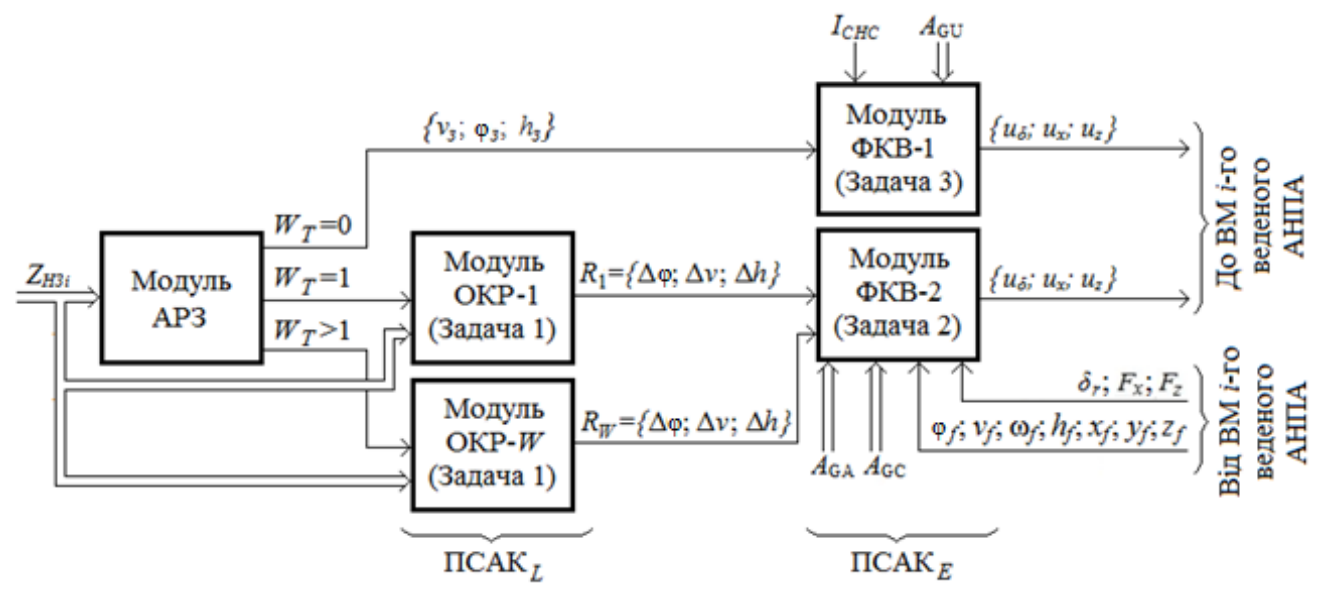

Рис. 6. Структура блоку «Бортовий керівний контролер» 
Тут на основі аналізу матриці $D_{H 3-К l i} \subset Z_{H 3 i}(11)$ шляхом сортування [26] обчислюється кількість їі ненульових елементів $W_{T} \leq W$ за виразом:

$W_{T}=\left\{\begin{array}{c}\left.0, \quad \text { якщо } D_{H 3-\kappa 1 i}=0 \quad \text { (нульова матриця } D_{H 3-K_{1} i}\right) ; \\ 1, \quad \text { якщо виявлено одиночну загрозу; } \\ >1, \quad \text { якщо виявлено більше однієї загрози. }\end{array}\right.$

Якщо $W_{T}=0$, це означає, що навігаційних загроз $i$-го веденого АНПА не виявлено і його САК виконує завдання № 3 «вирівнювання» згідно (1), тобто формує вимоги до ВМ АНПА на утримання стабільними трьох параметрів автоматичного групового руху: $v_{3}=v_{\text {MAS1 }} ; \quad \varphi_{\square} h_{3}=h_{\text {MAS1 }}$. У цьому випадку керуючі впливи $\left\{u_{\delta i} ; u_{x i} ; u_{z i}\right\}$ для ВМ $i$-го веденого АНПА обчислюються у модулі «Формування керуючих впливів-1» (ФКВ-1), де розв’язується завдання № 3 формування керуючих впливів для реалізації режиму $A_{\mathrm{GU}}$ «вирівнювання» $i$-го веденого АНПА. На цьому рисунку індекси $i$ при вихідних змінних модулів опущено для зручності сприйняття інформації.

Якщо $W_{T}=1$, це означає, що виявлено одну-єдину навігаційну загрозу, а іiі нейтралізацію слід виконувати, скориставшись рекомендаціями матриці $P_{H 3 i}$ (13). Для цього до структури БКК введено модуль «Обчислення керуючих рішень» (ОКР-1), де з використанням матриці рекомендацій $P_{H 3 i} \subset Z_{H 3 i}$ визначається керуюче рішення $R_{1}=\left\{\Delta \varphi_{i} ; \Delta v_{i} ; \Delta h_{i}\right\}$ для конкретної навігаційної ситуації з одним АНПА-сусідом. Керуючі впливи $\left\{u_{\delta i} ; u_{x i} ; u_{z i}\right\}$ для ВМ $i$-го веденого АНПА обчислюються у модулі «Формування керуючих впливів-2» (ФКВ-2), де розв'язується завдання № 2 реалізації його безпечного руху у складі групи АНПА 3 дотриманням вимог режимів адгезії $A_{\mathrm{GA}}$ та когезії $A_{\mathrm{GC}}$ (виконавчий рівень $E$ групового керу-

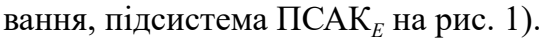

Найбільш складним є випадок, коли $W_{T}>1$. Це означає, що керуюче рішення $R_{i}=\left\{\Delta \theta_{i} ; \Delta v_{i} ; \Delta h_{i}\right\}$ згідно (15) треба шукати для кожної комбінації загроз окремо. Для обчислення таких рішень до складу блоку БКК уведено модуль «Обчислення керуючих рішень» (ОКР- $W)$, змістовна частина якого визначається кількістю $\mathrm{CHO}_{i}$ (кількістю контрольованих напрямків $W$ ) $i$-го веденого АНПА. Керуючі впливи $\left\{u_{\delta i} ; u_{x i} ; u_{z i}\right\}$ для ВМ $i$-го веденого АНПА при цьому також обчислюються у модулі ФКВ-2 (виконавчий рівень $E$ групового керування, підсистема ПСАК ${ }_{E}$ на рис. 1, блок Б11).

Так, за $W=4$ кількість комбінацій можливих навігаційних загроз дорівнює 11 і визначається кількістю парних, потрійних та однієї зчетвереної комбінації загроз, які виявляються сенсорами $\mathrm{CHO}_{i}$. Якщо носовий, правий, лівий і кормовий сенсори для $i$-го веденого АНПА позначити, відповідно, як $\mathrm{CHO}_{\mathrm{H}}$, $\mathrm{CHO}_{\Pi}, \mathrm{CHO}_{л}$ i $\mathrm{CHO}_{\kappa}$, отримаємо наступні комбінації напрямків можливих навігаційних загроз:
- дві одночасно виявлені загрози $\left(\mathrm{CHO}_{\mathrm{H}}+\mathrm{CHO}_{\Pi}\right) ;\left(\mathrm{CHO}_{\mathrm{H}}+\mathrm{CHO}_{Л}\right) ;\left(\mathrm{CHO}_{\mathrm{H}}+\mathrm{CHO}_{\mathrm{K}}\right) ;$ $\left(\mathrm{CHO}_{\mathrm{K}}+\mathrm{CHO}_{\Pi}\right) ;\left(\mathrm{CHO}_{\mathrm{K}}+\mathrm{CHO}_{Л}\right) ;\left(\mathrm{CHO}_{\Pi}+\mathrm{CHO}_{Л}\right)$; - три одночасно виявлені загрози + $\left(\mathrm{CHO}_{\mathrm{H}}+\mathrm{CHO}_{\Pi}+\mathrm{CHO}_{Л}\right) ;\left(\mathrm{CHO}_{\mathrm{K}}+\mathrm{CHO}_{\Pi}+\mathrm{CHO}_{Л}\right)$; $\left(\mathrm{CHO}_{\mathrm{H}}+\mathrm{CHO}_{\Pi}+\mathrm{CHO}_{\mathrm{K}}\right) ;\left(\mathrm{CHO}_{\mathrm{H}}+\mathrm{CHO}_{Л}+\mathrm{CHO}_{\mathrm{K}}\right)$;

- чотири одночасно виявлені загрози $\left(\mathrm{CHO}_{\mathrm{H}}+\mathrm{CHO}_{\Pi}+\mathrm{CHO}_{\Omega}+\mathrm{CHO}_{\mathrm{K}}\right)$.

Далі у розділі розглянемо $i$-й ведений АНПА $3 W=4$.

Очевидно, що для кожної з наведених можливих комбінацій навігаційних загроз, які визначені матрицею $D_{H 3 \text { - } 1 i}$ (при $W_{T}>1$ ), необхідно виконати синтез нечіткого регулятора. Розглянемо особливості синтезу такого регулятора для кожного типу комбінації загроз.

За наявності двох одночасно виявлених загроз типу $\left(\mathrm{CHO}_{\mathrm{H}}+\mathrm{CHO}_{\Pi}\right)$, які діють за різними осями зв'язаної системи координат, припустимим $є$ одночасне застосування двох рекомендацій типу (13), оскільки вони викликають маневри за різними напрямками руху $i$-го веденого АНПА.

У разі виявленні двох загроз, які діють за однаковими осями (наприклад, загрози $\left(\mathrm{CHO}_{\Pi}+\mathrm{CHO}_{Л}\right)$ діють по поперечній осі $y$ ), блок ОКР визначає найближчу по дистанції до загрозу $i$-го веденого АНПА і реалізує керування згідно до рекомендацій (13). Якщо дистанції до цих загроз однакові, виконується маневр швидкістю $\left(\Delta v_{w i} \neq 0\right)$ або глибиною занурення $\left(\Delta h_{w i} \neq 0\right)$.

Очевидно, що таке керівне рішення забезпечує $i$-му веденому АНПА постійне знаходження у складі групи завдяки наявності постійного гідроакустичного контакту з найближчим АНПА-сусідом і, таким чином, є обгрунтованим.

За наявності одночасно трьох загроз, які наближаються (гірший варіант сценарію підводного руху), модуль ОКР- $W$ має визначити дві найбільші загрози на зіткнення, а потім обчислити керуючі впливи згідно попереднього сценарію 3 двома загрозами. Водночас припустимим є горизонтальний маневр з метою ухилення від діючих загроз за напрямком $w$, з якого загроза відсутня.

За наявності одночасно чотирьох загроз, які наближаються до $i$-го веденого АНПА (найбільш небезпечний варіант сценарію підводного руху), модуль ОКР- $W$ має визначити дві найбільші загрози на зіткнення, а потім обчислити керуючі впливи на ухилення згідно попереднього сценарію з двома загрозами.

Водночас, оскільки маневр ухилення від найближчого АНПА-сусіда обмежений через наявність загрози 3 кожного контрольованого напряму, найбільш безпечною $є$ аварійна зміна глибини занурення $i$-го веденого АНПА.

\section{ОБГОВОРЕННЯ ОТРИМАНИХ РЕЗУЛЬТАТІВ}

Нині в науково-технічній літературі немає публікацій про автоматизацію окремого АНПА як «аген- 


\section{АВТОМАТИЗАЦІЯ ТА КОМП'ЮТЕРНО-ІНТЕГРОВАНІ ТЕХНОЛОГІЇ № 4〜 2020}

та» групи, а близькі за темою дослідження стосуються лише керування процесами загальної організації функціонування групи АНПА. Отримані у статті наукові результати стосуються розробки системи автоматичного керування веденого АНПА як «агента» групи підводних апаратів, які виконують спільну підводну пошукову місію. Така постановка питання автоматизації є важливою складовою загального процесу автоматичного керування груповим рухом АНПА, без успішного розв'язання якої неможливо створювати ефективні для практики системи автоматичного керування. Тому результати наведеного дослідження утворюють теоретичну основу для подальших прикладних інженерних розробок систем автоматичного керування узгодженим рухом групи АНПА, що дасть змогу підвищити продуктивність підводних пошукових робіт.

\section{ВИСНОВКИ}

1. На основі аналізу новітніх результатів у напрямку підводної робототехніки сформульовано актуальне прикладне наукове завдання розробки системи автоматичного керування безаварійним рухом одиночного веденого АНПА як «агента» групи в умовах навігаційної близькості інших підводних апаратів при виконанні ними спільної підводної пошукової місії.

2. Синтезовано узагальнений процес функціонування системи автоматичного керування веде- ним АНПА як «агентом» групи підводних апаратів, які виконують спільну підводну пошукову місію. Зазначений процес подано у вигляді узагальненого алгоритму функціонування системи автоматичного керування, який реалізує основні режими групового руху - вирівнювання, адгезію та когезію і передбачає широке застосування інформаційної складової функціонування веденого АНПА - використання інформації від його власних навігаційних сенсорів локального рівня автоматичного керування та додаткових сенсорів навігаційної обстановки навколо АНПА, моделювання навігаційної обстановки та ідентифікацію навігаційних загроз.

3. На основі отриманого алгоритму як методологічної основи розроблено структуру системи автоматичного керування веденим АНПА як «агентом» групи, яка включає блок «Сенсори навігаційної обстановки», блок «Модель навігаційної обстановки», блок «Ідентифікатор навігаційних загроз» та блок «Бортовий керуючий контролер», а також розроблено матричні інформаційні моделі функціонування вказаних блоків як теоретичне підгрунтя їх практичної реалізації.

4. Подальші дослідження планується проводити в напрямі розроблення матричних інформаційних моделей функціонування для всього переліку комбінацій можливих навігаційних загроз із боку сусідніх АНПА.

\section{REFERENCES}

[1] Ferber, J. (1999). Multi-Agent System: An Introduction to Distributed Artificial Intelligence. Addison Wesley Longman. URL: http://jasss.soc.surrey.ac.uk/4/2/reviews/rouchier.html

[2] Edward Fiorelli, Naomi Ehrich Leonard, Pradeep Bhatta, Derek Paley. (2004). Multi-AUV Control and Adaptive Sampling in Monterey Bay. - Proc. IEEE Autonomous Underwater Vehicles 2004: Workshop on Multiple AUV Operations (AUV04). URL: https://www.princeton.edu/ naomi/AUV13July04.pdf

[3] Mark Read, Christoph Möslinger, Daniela Kengyel, James Alan Hilder (2013). Profiling Underwater Swarm Robotic Shoaling Performance Using Simulation. Conference Towards Autonomous Robotic Systems, TAROS 2013: Towards Autonomous Robotic Systems, pp. 404-416. DOI: 10.1007/978-3-662-43645-5_42

[4] Hydromea Project. Retrieved from: https://www.hydromea.com/vertex-autonomous-underwater-swarm/

[5] NOC Presents New Robotic Microsub. Retrieved from: https://www.offshore-energy.biz/noc-presents-new-roboticmicrosub/

[6] Zanin V.Yu., Kozhemyakin I.V., Potekhin Yu.P., Putintsev I.A., Ryzhov V.A., Semenov N.N., Chemodanov M.N. (2017). Razrabotka avtonomnykh neobitaemykh podvodnykh apparatov klassa mikro s funktsiey gruppovogo upravleniya [The development of autonomous underwater vehicle class with the function of micro-group control]. Izvestiya YuFU. Tekhnicheskie nauki. no. 1-2 (186-187). Pp. 55-74. DOI 10.185.22/2311-3103-2017-1-5574. URL: https://cyberleninka.ru/ article/n/razrabotka-avtonomnyh-neobitaemyh-podvodnyh-apparatov-klassa-mikro-s-funktsiey-gruppovogo-upravleniya [in Russian]

[7] Gen'ichi Yasuda. (2015). Distributed Autonomous Control Architecture for Intelligent Mobile Robot Systems. Encyclopedia of Information Science and Technology, Third Edition. pp. 10. doi: 10.4018/978-1-4666-5888-2.ch650

[8] Jiang Dapeng, He Bin. (2014). Realistic Cooperative Control Mechanism of Multiple AUVs. Proceedings of the 33rd Chinese Control Conference. Pp. 1395-1400

[9] Michael R. Benjamin, Henrik Schmidt, Paul M. Newman, John J. Leonard. (2010). Nested Autonomy for Unmanned Marine Vehicles with MOOS-IvP. Retrieved from: http://140.117.95.8/teacher/PUB/conference/Abstract_Schmidt.pdf

[10] Cisco pxGrid: avtomatizatsiya peredachi dannykh po neskolkim platformam blagodarya unifitsirovannoy arkhitekture [Cisco pxGrid: automation of data transmission on multiple platforms through a unified architecture]. Retrieved from: https:/www.cisco.com/c/dam/global/ru_ru/about/brochures/assets/pdfs/white-paper-c11-735489.pdf. [in Russian]

[11] Liam Paull, S. Saeedi, H. Li. (2011). A Multi-Agent Framework for Autonomous Underwater Vehicles for Mine Countermeasures with MOOS-IvP. Pp. 1-10. 
[12] Marwah Almasri, Khaled Elleithy, and Abrar Alajlan. (2016). Sensor Fusion Based Model for Collision Free Mobile Robot Navigation. Sensors (Basel). Pp. 24. doi:10.3390/s16010024

[13] Taha Elmokadem, Mohamed Zribi, Kamal Youcef-Toumi. (2017). Terminal sliding mode control for the trajectory tracking of underactuated Autonomous Underwater Vehicles. Ocean Engineering. Volume 129, Pages 613-625. https://doi.org/10.1016/j. oceaneng.2016.10.032

[14] Huang Hai, Zhang Guocheng, Qing Hongde, Zhou Zexing. (2017). Autonomous underwater vehicle precise motion control for target following with model uncertainty. International Journal of Advanced Robotic Systems. Pp. 1-11. DOI: $10.1177 / 1729881417719808$

[15] Hajer Omrane, Mohamed Slim Masmoudi, and Mohamed Masmoudi. (2016). Fuzzy Logic Based Control for Autonomous Mobile Robot Navigation. Comput Intell Neurosci. Pp. 1-10. Retrieved from: https:/www.ncbi.nlm.nih.gov/pmc/articles/ PMC5027372/

[16] Anish Pandeya, Saroj Kumarb, Krishna Kant Pandeya, Dayal R. Parhia. (2016). Mobile robot navigation in unknown static environments using ANFIS controller. Perspectives in Science, Volume 8, pp. 421-423. Retrieved from: https://core.ac.uk/ download/pdf/81931273.pdf

[17] Aloba L.T. (2018) Struktura sistemy avtomaticheskogo upravleniya gruppovym dvizheniem ANPA [The structure of the automatic control system for the group movement of the AUV]. Pidvodna tekhnika i tekhnolohiia [Underwater engineering and technology]: Materialy Vseukrainskoi naukovo-tekhnichnoi konferentsii z mizhnarodnoiu uchastiu. Mykolaiv: NUK, Part 1, pp. 46-52. [in Russian]

[18] Radiohidroakustychni bui rozrobky Kyivskoho NDI Hidropryladiv [Radiohydroacoustic buoys developed by the Kyiv Research Institute of Hydraulic Devices]. OPK Ukrainy. Retrieved from: https://stailker.dreamwidth.org/274934.html [in Ukrainian]

[19] Santos, V. G.; Chaimowicz, L. (2014). Cohesion and segregation in swarm navigation. Robotica, 32(2), Cambridge University Press, pp. 209-223. Retrieved from: http://www.viniciusgraciano.com/research/cohesion-segregation/

[20] $1 \mathrm{MHz} / 200 \mathrm{KHz}$ Dual-frequency underwater distance ultrasonic sensor. Mode of access: URL:

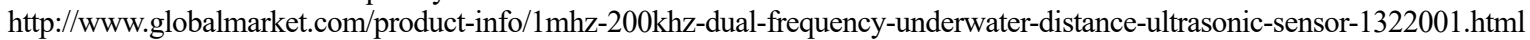

[21] Distance Keeping for Underwater Vehicles - Tuning Kalman Filters Using Self-Oscillations. Retrieved from: https://bib.irb.hr/datoteka/412520.Miskovic_et_al_OCEANS09_final_paper.pdf

[22] Gostev V.I. (2018) Nechetkie regulyatory v sistemakh avtomaticheskogo upravleniya [Fuzzy controllers in automatic control systems]. Kiev: Radioamator.

[23] Blintsov, O. (2017) Devising a method for maintaining manageability at multidimensional automated control of tethered underwater vehicle [Text]. Eastern-European Journal of Enterprise Technologies. Vol. 1, Issue 9. Pp. 4-16. doi: 10.15587/1729-4061.2017.93291

[24] Aloba L.T. (2019) Sintez intellektualnoy sistemy avtomaticheskogo upravleniya ANPA kak agentom gruppy [Synthesis of an intelligent automatic control system for AUV as a group agent]. Suchasni informatsiini ta innovatsiini tekhnolohii na transporti: Zbirka materialiv KhI Mizhnarodnoi naukovo-tekhnichnoi konferentsii. Kherson : Khersonska derzhavna morska akademiia. Pp. 224-227.

[25] Aloba L.T. (2019) Avtomatizatsiya gruppovogo upravleniya avtonomnymi neobitaemymi podvodnymi apparatami poiskovogo tipa [Automation of group control of autonomous unmanned underwater vehicles of the search type]. Pidvodna tekhnika i tekhnolohiia [Underwater engineering and technology]: Materialy IX Vseukrainskoi naukovo-tekhnichnoi konferentsii z mizhnarodnoiu uchastiu. Mykolaiv: NUK, Part 1, pp. 36-44. [in Russian]

[26] Melnychuk A.S., Lutsenko S.P., Hromovyi D.S., Trofymova K.V. (2013) Analiz metodiv sortuvannia masyvu chysel [Analysis of methods for sorting an array of numbers]. Tekhnologicheskiy audit i rezervy proizvodstva. No 4(1). Pp. 37-40. Retrieved from: http://nbuv.gov.ua/UJRN/Tatrv_2013_4-1_11 [in Ukrainian]

\section{СПИСОК ВИКОРИСТАНОЇ ЛІТЕРАТУРИ}

[1] Ferber, J. (1999). Multi-Agent System: An Introduction to Distributed Artificial Intelligence. Addison Wesley Longman. URL: http://jasss.soc.surrey.ac.uk/4/2/reviews/rouchier.html

[2] Edward Fiorelli, Naomi Ehrich Leonard, Pradeep Bhatta, Derek Paley. (2004). Multi-AUV Control and Adaptive Sampling in Monterey Bay. - Proc. IEEE Autonomous Underwater Vehicles 2004: Workshop on Multiple AUV Operations (AUV04). URL: https://www.princeton.edu/ naomi/AUV13July04.pdf

[3] Mark Read, Christoph Möslinger, Daniela Kengyel, James Alan Hilder (2013). Profiling Underwater Swarm Robotic Shoaling Performance Using Simulation. Conference Towards Autonomous Robotic Systems, TAROS 2013: Towards Autonomous Robotic Systems, pp. 404-416. DOI: 10.1007/978-3-662-43645-5_42

[4] Hydromea Project. Retrieved from: https://www.hydromea.com/vertex-autonomous-underwater-swarm/

[5] NOC Presents New Robotic Microsub. Retrieved from: https://www.offshore-energy.biz/noc-presents-new-roboticmicrosub/

[6] Занин В.Ю., Кожемякин И.В., Потехин Ю.П., Путинцев И.А., Рыжов В.А., Семенов Н.Н., Чемоданов М.Н. (2017). Разработка автономных необитаемых подводных аппаратов класса микро с функцией группового управления. Известия ЮФУ. Технические науки. № 1-2 (186-187). С. 55-74. DOI 10.185.22/2311-3103-2017-1-5574. URL: https://cyberleninka.ru/article/n/razrabotka-avtonomnyh-neobitaemyh-podvodnyh-apparatov-klassa-mikro-s-funktsieygruppovogo-upravleniya [in Russian] 
[7] Gen'ichi Yasuda. (2015). Distributed Autonomous Control Architecture for Intelligent Mobile Robot Systems. Encyclopedia of Information Science and Technology, Third Edition. pp. 10. doi: 10.4018/978-1-4666-5888-2.ch650

[8] Jiang Dapeng, He Bin. (2014). Realistic Cooperative Control Mechanism of Multiple AUVs. Proceedings of the 33rd Chinese Control Conference. Pp. 1395-1400

[9] Michael R. Benjamin, Henrik Schmidt, Paul M. Newman, John J. Leonard. (2010). Nested Autonomy for Unmanned Marine Vehicles with MOOS-IvP. Retrieved from: http://140.117.95.8/teacher/PUB/conference/Abstract_Schmidt.pdf

[10] Cisco pxGrid: автоматизация передачи данных по нескольким платформам благодаря унифицированной архитектуре. Retrieved from: https://www.cisco.com/c/dam/global/ru_ru/about/brochures/assets/pdfs/white-paper-c11-735489.pdf. [in Russian]

[11] Liam Paull, S. Saeedi, H. Li. (2011). A Multi-Agent Framework for Autonomous Underwater Vehicles for Mine Countermeasures with MOOS-IvP. Pp. 1-10.

[12] Marwah Almasri, Khaled Elleithy, and Abrar Alajlan. (2016). Sensor Fusion Based Model for Collision Free Mobile Robot Navigation. Sensors (Basel). Pp. 24. doi:10.3390/s16010024

[13] Taha Elmokadem, Mohamed Zribi, Kamal Youcef-Toumi. (2017). Terminal sliding mode control for the trajectory tracking of underactuated Autonomous Underwater Vehicles. Ocean Engineering. Volume 129, Pages 613-625. https://doi.org/10.1016/j. oceaneng.2016.10.032

[14] Huang Hai, Zhang Guocheng, Qing Hongde, Zhou Zexing. (2017). Autonomous underwater vehicle precise motion control for target following with model uncertainty. International Journal of Advanced Robotic Systems. Pp. 1-11. DOI: $10.1177 / 1729881417719808$

[15] Hajer Omrane, Mohamed Slim Masmoudi, and Mohamed Masmoudi. (2016). Fuzzy Logic Based Control for Autonomous Mobile Robot Navigation. Comput Intell Neurosci. Pp. 1-10. Retrieved from: https://www.ncbi.nlm.nih.gov/pmc/articles/ PMC5027372/

[16] Anish Pandeya, Saroj Kumarb, Krishna Kant Pandeya, Dayal R. Parhia. (2016). Mobile robot navigation in unknown static environments using ANFIS controller. Perspectives in Science, Volume 8, Pp. 421-423. Retrieved from: https://core.ac.uk/ download/pdf/81931273.pdf

[17] Алоба Л.Т. (2018) Структура системы автоматического управления групповым движением АНПА. Підводна техніка i технологія: Матеріали Всеукраїнської науково-технічної конференції з міжнародною участю. Миколаїв: НУК, Ч. 1. C. 46-52. [in Russian]

[18] Радіогідроакустичні буї розробки Київського НДІ Гідроприладів. ОПК України. Режим доступу: https://stailker.dreamwidth.org/274934.html [in Ukrainian]

[19] Santos, V. G.; Chaimowicz, L. (2014). Cohesion and segregation in swarm navigation. Robotica, 32(2), Cambridge University Press, pp. 209-223. Retrieved from: http://www.viniciusgraciano.com/research/cohesion-segregation/

[20] $1 \mathrm{MHz} / 200 \mathrm{KHz}$ Dual-frequency underwater distance ultrasonic sensor. Mode of access: URL: $\mathrm{http}: / /$ www.globalmarket.com/product-info/1 mhz-200khz-dual-frequency-underwater-distance-ultrasonic-sensor-1322001.html

[21] Distance Keeping for Underwater Vehicles - Tuning Kalman Filters Using Self-Oscillations. Retrieved from: https://bib.irb.hr/datoteka/412520.Miskovic_et_al_OCEANS09_final_paper.pdf

[22] Гостев В.И. (2018) Нечеткие регуляторы в системах автоматического управления. Киев: Радиоаматор.

[23] Blintsov, O. (2017) Devising a method for maintaining manageability at multidimensional automated control of tethered underwater vehicle [Text]. Eastern-European Journal of Enterprise Technologies. Vol. 1, Issue 9. Pp. 4-16. doi: 10.15587/1729-4061.2017.93291

[24] Алоба Л.Т. (2019) Синтез интеллектуальной системы автоматического управления АНПА как агентом группы. Сучасні інформаційні та інноваційні технологї̈ на транспорті: Збірка матеріалів ХІ Міжнародної науково-технічної конференції. Херсон : Херсонська державна морська академія. С. 224-227.

[25] Алоба Л.Т. (2019) Автоматизация группового управления автономными необитаемыми подводными аппаратами поискового типа. Підводна техніка і технологія: Матеріали IX Всеукраїнської науково-технічної конференції 3 міжнародною участю. Миколаїв: НУК, Ч. 1. С. 36-44. [in Russian].

[26] Мельничук А.С., Луценко С.П., Громовий Д.С., Трофимова К.В. (2013) Аналіз методів сортування масиву чисел. Технологический аудит и резервы производства. № 4 (1). C. 37-40. URL: http://nbuv.gov.ua/UJRN/Tatrv_2013_4-1_11 [in Ukrainian].

(C) В. С. Блінцов, Л. Т. Алоба Дата надходження статті до редакції: 08.12.2020 Дата затвердження статті до друку: 18.12.2020 